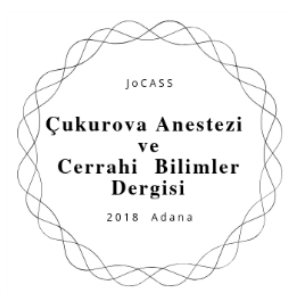

\title{
PAPILLARY THYROID CARCINOMA WITH RARE METASTASES TO COSTA AND VERTEBRAE: CASE REPORT
}

KOSTA VE VERTEBRAYA NADIR METASTAZ GÖSTEREN PAPILLER TİROID KARSINOMU: OLGU SUNUMU

\author{
Zafer Şenol ${ }^{1}$ Taygun Gülşen ${ }^{1}$ \\ 1 Sultan Abdulhamid Han Training and Research Hospital, Department of General Surgery, Istanbul, Turkey \\ Sorumlu Yazar/Corresponding Author: Zafer Şenol E-mail: zafersenol@yahoo.com \\ Geliş Tarihi/Received: 02.02.2021 Kabul Tarihi-Accepted: 28.02.2021 Available Online Date/Çevrimiçi Yayın Tarihi: 30.04 .2021 \\ Cite this article as: Şenol Z, Gülşen T. Papillary Thyroid Carcinoma with Rare Metastases to Costa and Vertebrae: Case Report \\ J Cukurova Anesth Surg. 2021;4(1):20-23. Doi: 10.36516/jocass.2021.68 \\ (iD) $0000-0002-6865-3716,0000-0002-4536-7776$
}

\begin{abstract}
Papillary thyroid carcinoma (PTC) is the most common pathological type of differentiated thyroid cancer, which accounts for about 80\% of all thyroid carcinomas. PTC has a slow progressing behavior, distant metastases are rare, indicating aggressive behavior of the disease. Bone metastasis of PTC is very rare at around 1-7\%. In this case report, the diagnosis and treatment of unusual PTC metastases observed in costa and vertebrae of a 57 -year-old male patient is presented. The patient had a history of subtotal thyroidectomy 26 years ago. The presented case indicates that PTC metastases can be observed in unusual areas long after the treatment of the primary tumor.
\end{abstract}

Keywords: Papillary thyroid carcinoma, metastasis, costa, vertebrae

Öz

Papiller tiroid karsinomu, tüm tiroid karsinomlarının yaklaşık \%80'ini oluşturan, diferansiye tiroid kanserinin en yaygın patolojik türüdür. Papiller tiroid karsinomunun yavaş ilerleyen bir davranışı vardır, uzak metastazlar nadirdir ve hastalı̆ın agresif davranışını gösterir. Papiller tiroid karsinomunun kemik metastazı \%1-7 civarında çok nadirdir. Bu olgu sunumunda, 57 yaşındaki erkek hastanın kosta ve vertebrasında görülen olağandışı papiller tiroid karsinomu metastazlarının tanı ve tedavisi sunulmuştur. Hastanın 26 yı önce subtotal tiroidektomi öyküsü vardı. Sunulan vaka, papiller tiroid karsinomu metastazlarının, primer tümörün tedavisinden uzun süre sonra sıra dışı bölgelerde gözlemlenebileceğini göstermektedir.

Anahtar Sözcükler: Papiller tiroid karsinomu, metastaz, kosta, vertebra 
Introduction

Papillary thyroid carcinoma (PTC), a type of differentiated thyroid carcinoma (DTC), is the most prevalent type of thyroid malignancy accounting for about $80 \%$ of all cases of thyroid cancers ${ }^{1}$. DTC is the most common type of thyroid cancer with a prevalence of $90 \%$ of all thyroid cancers $^{2}$ and includes some other subtypes such as follicular thyroid carcinoma (FTC), Hurthle cell carcinoma, and poorly differentiated histologies ${ }^{3}$. When diagnosed early, the well-differentiated thyroid carcinomas such as PTC and FTC have generally good prognosis and survival rate ${ }^{4}$. PTC is a follicle-derived (thyroid epithelial) carcinoma and usually has a slowly progressive behavior with infrequently observed distant metastases suggesting an aggressive manner of disease $^{5}$. Distant metastases of PTC are reported to be rare with a range of $1.73 \%$ $8.4 \%$ in most studies ${ }^{6}$ and may appear less often in bones, liver, central nervous system, kidney, pericardium and pleura, skin, pancreas, muscle, and gastrointestinal $\operatorname{tract}^{7}$. In this case report, the diagnosis and treatment of PTC with rare metastases observed in costa and vertebrae is presented.

\section{Case Presentation}

A 57-year-old male patient applied to Sultan Abdulhamid Han Training and Research Hospital with complaints of pain in abdomen and in the left side of his chest in February 2019. The patient had a history of subtotal thyroidectomy 26 years ago in a different hospital. Destruction in the patient's eighth costa was detected from the results of Computed Tomography (CT) scanning. The patient underwent Positron Emission Tomography (PET) CT and a mass with size of $10 \mathrm{~cm} \times 6 \mathrm{~cm}$ SUD Max 4.22 was observed on and around his eighth costa. The mass was diagnosed as PTC metastasis according to biopsy results. The Magnetic Resonance Imaging
(MRI) images of the metastatic tumor in costa are shown in Figure 1.
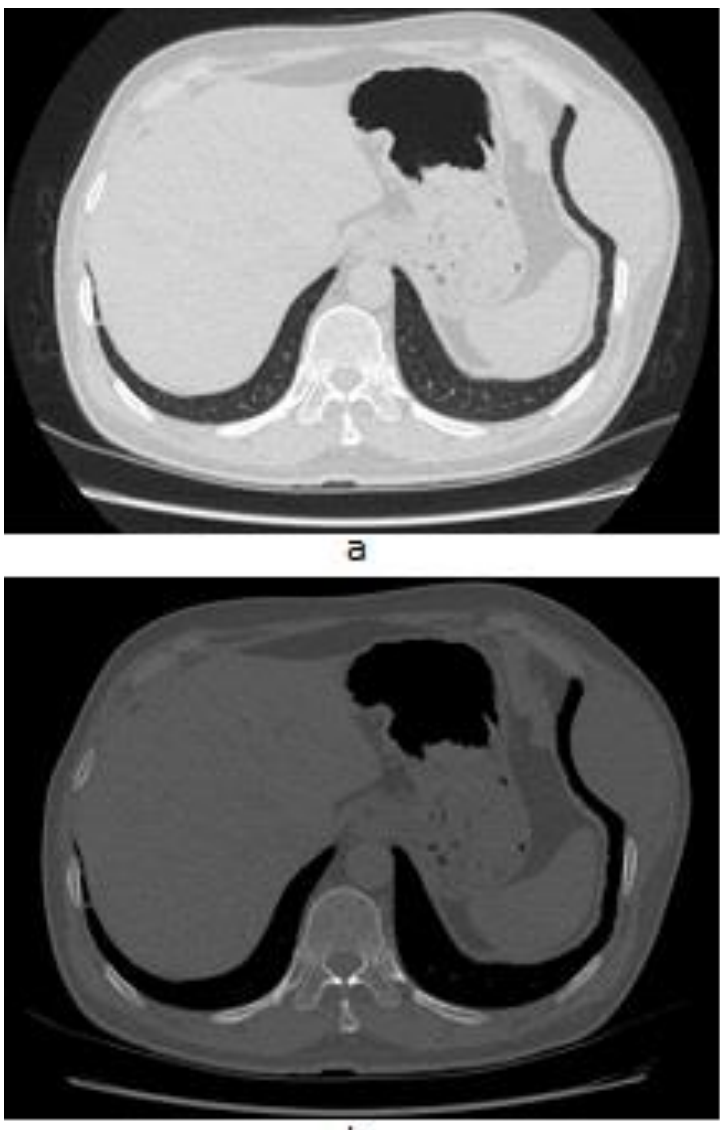

b

Figure 1. MRI images of PTC metastasis to costa (a) parenchymal view (b) bone view

The patient underwent left thoracotomy and resection of the metastatic costa in eighth costa by thoracic surgery in May 2019. In following months, the patient had low back pain complaint. According to the results of the examinations, a metastatic lytic mass with dimensions of $36 \mathrm{~mm} \times 23$ $\mathrm{mm}$ in the patient's T8 vertebrae was observed which was also diagnosed as thyroid carcinoma metastasis. The MRI image of metastatic lytic mass observed in T8 vertebrae is shown in Figure 2. For the treatment of the metastatic lytic mass in vertebrae, T8 metastatic mass extraction, T8 partial and T9 total corpectomy operation was performed by the neurosurgery clinic in July 2019. 


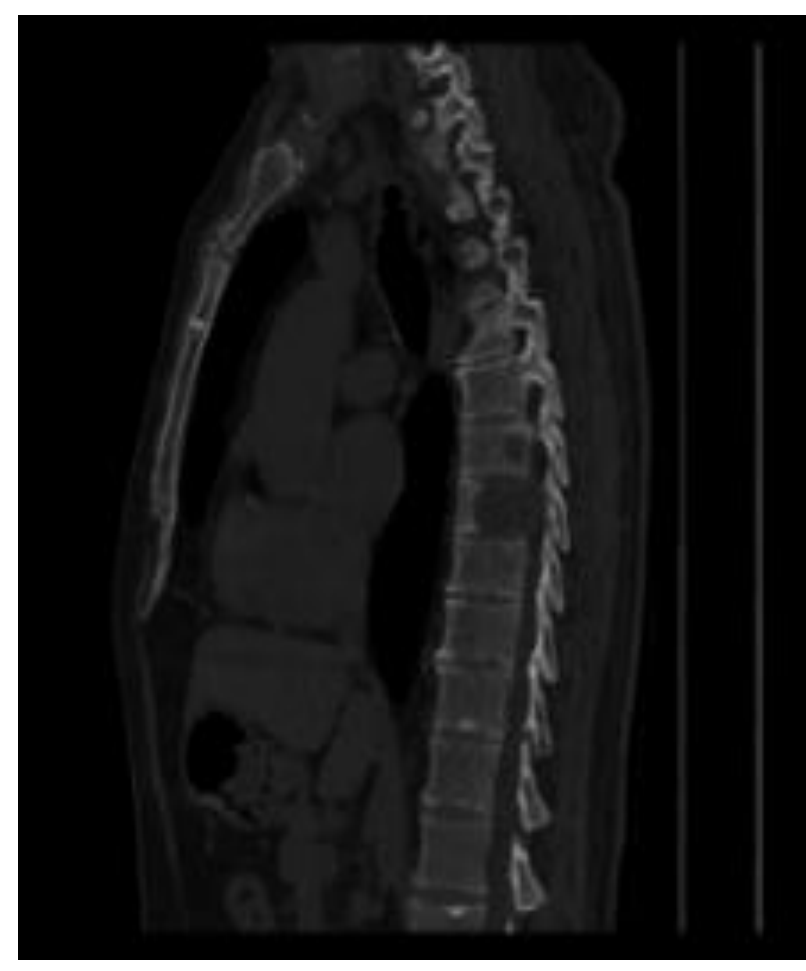

Figure 2. MRI image of PTC metastasis to T8 vertebrae

\section{Discussion}

The most common type of thyroid malignancy observed in the patients with thyroid nodules is PTC (80\%) followed by FTC $(20 \%)^{8}$. PTC, the most common type of differentiated thyroid carcinoma, has a non-aggressive nature. This malignancy usually shows a slowly progressive behavior and thyroidectomy is often curative. PTC is rarely a congenital tumor, can occur at any age during the life, with a mean age of 40 years, usually observed in the third to fifth decades of the life of patients. PTC incidence increases with age and is observed more frequently in women than men with a ratio of $2: 1$ to $4: 1^{9}$. Surgery is usually the first treatment of choice for PTC. In the treatment of PTC, total thyroidectomy is followed by Radioactive Iodine (RAI) therapy ${ }^{10}$. Follicular variant of papillary thyroid carcinoma (FV-PTC) is the most common sub-type of PTC with an incidence of $9 \%$ $-22.5 \%$ of all PTC cases ${ }^{11}$.

In the literature, in a retrospective analysis including metastatic DTC cases of 1038 patients, 44 of them were reported to have distant metastases, and among those only 19 of them were with PTC ${ }^{12}$. PTC and FTC have different patterns of metastases. It was reported that PTC has a lower incidence of bone metastases $(1.4 \%-7 \%)$ in comparison to FTC $(7 \%-28 \%)^{13}$. In another study, the incidence of bone metastases of PTC was found as $0.6 \%$ $6.9 \%$ while FTC metastases was founded as $15.2 \%-33.7 \%^{14}$.

In the presented case report, rare metastases of PTC to costa and vertebrae observed in a male patient are presented. The patient, who had a history of subtotal thyroidectomy 26 years ago, was diagnosed with PTC metastases seen in his eighth costa and T8 vertebrae. After mass resection in costa performed by thoracic surgery, metastatic mass excision in $\mathrm{T} 8$, T9 total and T8 partial corpectomy carried out by neurosurgery. In general surgery, bilateral supplementary thyroidectomy operation was performed, and the patient's surgical treatment was completed successfully.

\section{Conclusion}

Distant metastases are relatively uncommon in patients with welldifferentiated thyroid carcinomas. Bone metastases of PTC are reported to be very rare in the literature. In this case report, very rare PTC metastases to costa and vertebrae observed 26 years after the primary carcinoma is presented. This reveals that PTC, which tends to have a slow progressive behavior and rare distant metastases, may also metastasize to unusual regions long period after the primary tumor is seen. 


\section{Conflict of interest}

The authors declared they do not have anything to disclose regarding conflict of interest with respect to this manuscript.

\section{Funding}

None

\section{Ethical approval}

Ethical approval for this study was obtained by Ethics Committee of Health Sciences University, Istanbul, with number of 2020/1.

\section{References}

1. Zhu X, Yao J, Tian W. Microarray technology to investigate genes associated with papillary thyroid carcinoma. Mol Med Rep. 2015;11:3729-33. https://doi.org/10.3892/mmr.2015.3180

2. Schneider DF, Chen H. New developments in the diagnosis and treatment of thyroid cancer. CA Cancer J Clin. 2013;63:374-94. https://dx.doi.org/10.3322/caac.21195

3. Haraldsdottir S, Shah MH. New era for treatment in differentiated thyroid cancer. Lancet 2014;384:286-8.

https://dx.doi.org/10.1016/S01406736(14)60663-2

4. Paricharttanakul NM, Saharat K, Chokchaichamnankit $\mathrm{D}$, et al. Unveiling a novel biomarker panel for diagnosis and classification of well-differentiated thyroid carcinomas. Oncol Rep 2016;35:2286-96. https://doi.org/10.3892/or.2016.4567

5. Song HJ, Xue YL, Qiu ZL, et al. Uncommon metastases from differentiated thyroid carcinoma. Hell J Nucl Med 2012;15:233-40. https://dx.doi.org/10.1967/s002449910059

6. Sugitani I, Fujimoto Y, Yamamoto N. Papillary thyroid carcinoma with distant metastases: survival predictors and the importance of local control. Surgery 2008;143:35-42.

https://dx.doi.org/10.1016/j.surg.2007.06.011

7. Chrisoulidou A, Boudina M, Tzemailas A, et al. Histological subtype is the most important determinant of survival in metastatic papillary thyroid cancer, Thyroid Res, 2011;4:12. https://dx.doi.org/10.1186/1756-6614-4-12
8. Rahman MM, Karim MA, Arafat MS, et al. Frequency of malignancy in multinodular goitre. Bangladesh J Otorhinolaryngol 2015;20:75-9.

https://dx.doi.org/10.3329/bjo.v20i2.22022

9. LiVolsi VA. Papillary thyroid carcinoma: An update. Mod Pathol; 24 Suppl 2011;2:S1-9. https://dx.doi.org/10.1038/modpathol.2010.129

10. Shrestha SK, Joshi MR, Sharma SK. Total thyroidectomy: the treatment of choice in differentiated thyroid carcinoma. Kathmandu Univ Med J (KUMJ) 2005; 3:3538.

11. Lam AK, Lo CY, Lam KS. Papillary carcinoma of thyroid: a 30-yr clinicopathological review of the

variants. EndocrPathol 2005;16:323-30. https://dx.doi.org/10.1385/ep:16:4:323

12. Shaha R, Shah JP, Loree TR. Differentiated thyroid cancer presenting initially with distant metastasis. Am J Surg 1997;174:474-6. https://doi.org/10.1016/S0002-9610(97)00158X

13. Kuschayeva YS, Kuschayev SV, Carroll NM, et al. Spinal metastases due to thyroid carcinoma: an analysis of 202 patients. Thyroid 2014;24:1488-500.

https://dx.doi.org/10.1089/thy.2013.0633

14. Sampson E, Brierley JD, Le LW, et al. Clinical management and outcome of papillary and follicular (differentiated) thyroid cancer presenting with distant metastasis at diagnosis. Cancer 2007;110:1451-6. https://dx.doi.org/10.1002/cncr.22956 